$<$ 特別講演 $2>$

\title{
3 次元画像計測の各種実施例
}

長崎大学工学部教授 石松隆和

\section{1.はじめに}

近年の目覚ましいコンピュータやエレクトロニクス技術の発達により、以前 からアイデアとしてはあったが、実現が難しかった技術のいくつかが、現実の ものとなりつつある。3 次元画像計測もまさにその典型的な例で、従来はモア レカメラの画像を長時間をかけて解析していたのが、パソコンで、数秒程度で 計測が可能で、しかも即座に動く 3 次元 C G として表示できるようになってい る。 3 次元形状計測装置の值段は、まだ廉いとは言い難いが、近い将来には、 安価に、コンパクトに、高精度になると思われる。3 次元画像計測に関してつ くづく痛感するのは、単に 3 次元計測手法の発達だけではなく、他の関連する 技術があって始めてこれほど発展してきたことである。本講演では、画像を使 った計測がどのように行われているかを、各種の事例を紹介すると同時に、関 連する事例についても触れる。

\section{3 次元形状計測の実例（光切断法に基づく方法）}

測定したい物体上でスリット状のレーザー光を走査し、その映像をコンピュ 一夕処理することにより、対象物の 3 次元形状が短時間で得られる。計測時間 を短縮化するため、縞模様の光を当てる等の工夫がなされており、人体や小物 体等の計測結果とあわせて紹介する。

\section{3. 多方向からの写真を使う 3 次元形状計測}

人間は、様々の方向から対象物を眺めることで、その立体形状を想像するこ とができる。画像処理においても、複数方向からとった対象物の画像を解析す ることで、対象物の立体形状を求めることができる。すでにそのようなソフト ウェアも市販されている。ここでは、長崎の平和祈念像と、長崎近郊の丘に算 える奇岩を測定した結果について述べる。

4. 2 枚のカメラを使った顎関節の 3 次元的な動きの解析

下顎に光マークを設置し、頭に取り付けた 2 台のテレビカメラでその光マー クの 3 次元的な動きを調心、顎の動きを解析する装置を試作した。その装置に ついて紹介する。 
5. カメラによる人体頭部の 3 次元的な動きの解析

頭部に光マークを 3 点設け、台上に設置したテレビカメラで光マークの動き をリアルタイムで調べ、頭部の 3 次元的の動きを測定する装置を、極めて安価 （2 万円程度）コンパクトに製作し、身障者のためのキーボード代替装置とし て使用した例を紹介する。

6. 各種移動機械の制御への 3 次元画像計測の利用

人間が目で行っているへリコプターのホバリング制御や電動車イスの走行制 御、さらに自動車の走行制御を、コンピュータへ置き換えることも可能で、3 次元画像計測手法が使われ成功している様子を紹介する。また、大いに発展が 期待されているサービスロボット（パーソナルロボット）についても触れる。 